\title{
Socio-Economic Characteristics and Food Consumption Pattern of Rural Women
}

\author{
Maruthesha, A.M. ${ }^{1}$, Vijayalakshmi. D. ${ }^{2}$ Pritham, S.M. ${ }^{3}$ \\ Vijay, S. Danaraddi ${ }^{4}$ Sandya, S. Ryavanki ${ }^{5}$ \\ ${ }^{1}$ Assistant Professor, Department of Food Science, Agricultural and Horticultural Research Station, \\ Kathalagere. University of Agricultural and Horticultural Sciences, Shivamogga, Karnataka, India \\ ${ }^{2}$ Professor, Department of Food Science and Nutrition, College of Agriculture,University of Agricultural \\ Sciences, GKVK, Bangalore, Karnataka, India \\ ${ }^{3}$ Junior Research Fellow, Department of Food Science and Nutrition, Agricultural and Horticultural Research \\ Station, Kathalagere, University of Agricultural and Horticultural Sciences, Shivamogga, kartnataka, India. \\ ${ }^{4}$ Technical Assistant, AICRP-IFS, Agricultural and Horticultural Research Station, Kathalagere, University of \\ Agricultural and Horticultural Sciences, Shivamogga, India. \\ ${ }^{5}$ Guest Lecturer,Department of Food Processing and Nutrition, Karnataka State Women University, Vijayapura, \\ Karnataka, India
}

\begin{abstract}
This study has focused on the functioning of 10 SHG's located in Venkatahalli and Heggadehalli villages of Bangalore rural district comprising of 200 farmwomen mainly belonging to marginal and landless category with age group of 18-35 years. The women members of SHG's were found to save a portion of their meager income and pool that money for lending among them at an interest decided by the group. A close look at the pattern of lending revealed that most part of the credit was used for improving the sustainability of their agriculture and economic status as the loans were availed for crop cultivation, purchase of milch animals and sericulture activities. It was observed that majority of the rural families consumed 3 meals per day and only 18 per cent of the rural families consumed 2 meals per day. The diet of the rural families was monotonous, lacking variety and they care more for bulk rather than quality of the diet. Nutrient intake of rural women was compared with RDA. The intake of all nutrients viz. energy, protein, fat, iron, thiamine, riboflavin, niacin and $\beta$ carotene were low except for calcium. The per cent adequacy of nutrients was inadequate.
\end{abstract}

Key Words:Food pattern, rural women and empowerment, Socio Economic status

\section{Introduction}

The social and economic status of women is a reliable indicator of their empowerment in a society. The often-repeated argument is that women development or empowerment is possible only if they are given opportunities to develop freedom and participate in socio economic programs. There is an exhaustive list of goals to be achieved through self-help program which empower women; saving habits, credit for production and consumption purposes, opportunities for entrepreneurship, functional literacy, developing leadership qualities, gender sensitivity and awareness about the socio-political, economic and cultural issues (Ashwathiet al, 2001). The empowerment of women through Self Help Groups (SHGs), a non-formal cooperative organization would benefit not only the individual women but also the family and community as a whole through collective action for development. These SHG's have a common perception of need and an impulse towards collective action (Bharathi and Chaya, 2008). Micro finance is making headway in its effort for eradicating poverty and empowering women (Jayalakshmi, 1998). Micro finance interventions are well organized all over the world as effective tools for poverty alleviation and improving socio-economic status of poor and marginalized mainly through women SHGs. The women SHGs involved in micro finance projects are well organized in terms of formation and stabilization for extending credit support and promotion of thrift to promote viable economic activities in the backward areas has resulted in empowerment of women belonging to low socio-economic strata. Empowering women needs a holistic approach to participate in decision-making in the household, community and local democratic sector and prepare women to take up leadership position in agricultural activities. SHGs in rural India are causing a silent revolution not only in terms of providing micro credit but also by contributing in other forms to make the agriculture sustainable. In this backdrop, the present study is an attempt to understand the various activities undertaken by SHGs to empower rural women. The specific objectives of the study are:

1. To understand the social and economic empowerment of the women members of SHGs

2. Elicit the existing information on small scale entrepreneurial activities among SHG rural households

3. To assess the dietary pattern of rural SHG women 


\section{Methodology}

The above objectives of the study were achieved through quantitative as well as qualitative assessments. The study was conducted in two villages of Bangalore rural district, Karnataka. Totally 10 SHG's have been selected for the study. Each group consists of about 19 to 20 women members. Information was elicited from all the members of 10 SHG's, which together formed 200 women members, constituting the sample. The data was collected with the help of semi-structured interview schedule. The schedule included questions relating to the family income, savings and loan schemes available to SHG members. Focus group discussions were also conducted to crosscheck the collected data. Secondary information was collected from books, ledgers and registers maintained by SHG's. The data on socio-economic status related to the age, education, and type of family, family size, occupation and land holdings and income of the family. Dietary pattern was assessedby 24 hour recall method for 7-days. Sets of pre standard vessels were used to obtain estimates of raw and cooked foods consumed by the subjects. Subsequently, the individual consumption of nutrients like energy, protein, fat, iron, calcium, thiamine, riboflavin and niacin were calculated using food composition table and compared with the recommended dietary allowance (Gopalanet al.2007) and the adequacy of nutrients was calculated as per Thimmayamma (1987).

\section{Results And Discussion \\ 1. Socio -Demographic Profile of Women Members of SHG'S:}

Socio-economic characteristics of rural women were depicted in Table 1. It was observed that majority of rural women were found to be in age group 21- 25 years, followed by 26- 35 years. Middle aged women are generally enthusiastic and innovative nature. The young women will be having the indication to take risks and need for achievement in general. The findings are in conformity with those findings of Tara and Negi (2012), who have revealed that majority of the rural women belonged to middle age group.

Most of the rural women $(33.00 \%)$ were illiterates. About34 per cent of them had primary school followed by 12 per cent secondary school, 14 per cent had high school level of education, and remaining 7 per cent of the rural women were graduates. These findings are in line with the findings of Mamatha and Chaya (2012) who observed that majority of rural women studied upto primary school level.Occupation of the rural women that is 26 per cent of them were housewives, 40 per cent of them labourers, 24 per cent of them were involved in dairy, 6 per cent in sericulture and 4 per cent in other activities. These findings are in line with George et al. (2009) and Gurumeet and Gurudarshan (2011).It was observed that majority of the rural families $(63.00 \%)$ were marginal farmers, 16 per cent of them were small farmers, 11 per cent of them were medium farmers and only 10 per cent were land less.Land holding of the subjects indicated that majority of them belonged to the marginal land holding category $(63.00 \%)$ followed by small farmer category $(16.00 \%)$. It clearly indicates that the low economic status particularly rural women have low earning power and also may be because of the fragmentation and subdivision of agricultural lands by the members of the family. The findings of the present study agree with the findings of Revanna (2006) and Rakshaet al. (2011).From the same table it is clear that 16 per cent of the rural families' income ranged between Rs. 2,000-3,000, followed by 56 per cent with the income of Rs. 3,000 per month. And only 28 per cent of the families are in the range of Rs.4,000Rs.5,000. These findings have also been observed by Mamatha and Chaya (2012) who reported the income position of the family indicated that majority $(85.00 \%)$ of the respondent belonged to the medium income group followed by high income group (10.00\%) and low income group $(5.00 \%)$.

\section{SHG Formation:}

Existing women SHGs in the study area are presented in Table 2. The women formed SHG's primarily to make savings and pool their limited resources to meet their financial requirements. Among the study villages totally ten SHG were actively involved in various functions. Majority of the SHG groups were having 19-21 members in each group with the collection of Rs.10 per week. Among the SHGs groups, Chandrodaya SHG group and Jaymatha SHG's groups were having highest savings of Rs.46,080 per month, followed by Maheshwari group Rs.38,400 per month. Chandrodaya and Jaymatha SHG groups were functioning for past 6 years, followed by Maheshwari group and majority of the SHG's had taken loan for the purchase cattle and sheep followed by education loan. Women save a small portion of their meagre income and pool the money which they lend among themselves at an interest rate decided by the group as a whole. A close look at the pattern of lending shows that, credit facilities were availed for meeting the charges on crop cultivation, purchase of milch animals, sericulture activities, purchasing of tailoring unit and also repayment of loan. Thus most part of the credit was used for improving the sustainability of their agriculture and economic status. These findings are supported from the study conducted by Kavitha and Deepa (2013).

Base line survey results (Table 3) showed that overall 31 per cent of the respondents were engaged in dairy farming followed by vegetable marketing (30.00\%), sheep rearing (19.00\%)etc. and only 1.5 per cent was engaged in vermicomposting. From the study it was clear that none of the respondents had undergone any 
of the training programmes related to entrepreneurial development. Veena (2009) reported that, training programme was one of the tools for enhancement of skills and value addition activities among the SHG women. Also it was helpful for empowerment of SHG members and training programmes enhance the self-confidence, leadership qualities, skills to undertake value addition activities, enhances income, utilisation of protective foods and better knowledge. A similar finding on mushroom cultivation has entrepreneurial activity among SC/ST rural women as reported by Viajayalakshmiet al. (2008).

\section{Dietary Pattern of SHG Families:}

Food habits of the rural families are shown in Table 4. It was observed that, all the rural families were non-vegetarians by habit, food of animal sources were being consumed twice week by 49 per cent of the families, followed by once a week (18.50\%) and fortnightly (32.50\%). These findings are in line with the observation of Vijayalakshmiet al. (2008) who observed that majority of the rural families were non-vegetarians and consumption of all commodities was much lower than the RDA. It is clearly evident from the same table that 18 and 82 per cent of the rural families consumed two and three meals respectively. Majority of the households were in the habit of preparing the food twice a day $(86.00 \%)$.

\section{Nutrient Intake:}

The diet of the rural families was monotonous lacking variety and they care for more bulk rather than quality of the diet. The common meal pattern of the rural families was cereal for breakfast and rice with vegetables or dhal and finger millet dumpling for dinner. The mean intake of nutrients by women namely, protein, fat, energy, calcium, iron, $\beta$-carotene, thiamine, riboflavin and niacin are presented in Table 5 . The adequacy of nutrients was below recommended dietary allowances. The deficit of nutrient intake of rural women was compared with RDA which depicted significance at 1 per cent level. Intake of energy $1850 \mathrm{kcal}$, protein $35.3 \mathrm{~g}$, fat $16.3 \mathrm{~g}$, iron $14.7 \mathrm{mg}$, thiamine $0.8 \mathrm{mg}, \beta$ - carotene $3600 \mathrm{mg}$, riboflavin $0.8 \mathrm{mg}$ and niacin $11 \mathrm{mg}$ were low. But calcium (695 mg) intake was higher compared to RDA due to the consumption of finger millet which is the staple crop. These findings fall in line with the findings reported by Revanna (2006) who reported that majority of the rural women were deficit in all the nutrients. An increment in food intake is always associated with an increment in energy intake. It was observed that the mean intake of energy by women in the study group were not up to the recommended levels. The findings reported by DobhalandRaghuvanshi (2011) found that energy intake of rural women was less than recommended dietary allowances.

Correlation co-coefficient of selected socio-economic factors onnutrient intake is shown in Table 6. Age had a positive relationship with protein intake in rural women further there exists a positive relationship of education factor with energy and calcium, iron, thiamine, riboflavin except niacin intake. Type of family had negative relationship with protein, fat, calcium, iron, thiamine intake. Land holding had a positive relation with energy,protein, fat, calcium and $\beta$-carotene. Family income had a positive relation with the entire nutrient intake.The findings are in concurrence with the findings of Masanta and Pradhan (2011) who reported that increase in household size decreased the nutrient intake. As income increases, intake of energy, protein, fat, calcium, iron, thiamine, riboflavin, niacin and $\beta$-carotene also increased. These findings are supported by Vijayalakshmi (2008) who reported that as income and education status increases, nutrient consumption also increases.

\section{Conclusion}

The study made an effort to understand the role of SHG in socio-economic empowerment of women. SHG women members utilized the credit availed for productive purposes which contributed substantially to their family development. The saving capacities of the households have also increased after formation of SHG. Majority of the women are taking loan for purchase of cattle, sheep and few of them wanted to setup processing units. Majority of women were engaged in dairy farming, vegetable marketing and sheep rearing. The dietary pattern of women members of SHG indicated that the consumption level of energy, protein, fat and minerals were far below RDA. The diet of rural families was monotonous, lacking variety and they care more for bulk rather than quality of the diet. Education, land holding, income and age had significant and positive association with nutrient intake among rural SHG women groups.

\section{References}

[1]. AHWATHI, P. K., RATHI AND SAHU, V., 2007, Working and impact of SHGs on economic status of women in watershed area of Madhya Pradesh. Ind. J. of Agric.Econ., 56(3): 475-476.

[2]. BHARATHI, R. AND CHAYA B ADIGER, A., (2008), "Impact of National Agricultural Technology Project on empowerment of women in Agriculture through Self Help Groups".Kar. J.Agril.sci.,21(4): 561-564.

[3]. DOBHAL, N. AND RAGHUVANSHI, R.S., (2011), "Nutritikon and health status of urban and rural women of Garhwal Region". Ind. J. Nutri and Dietet., 48(9): 377-389.

[4]. GEORGE, P.R., SHIBU, C.N. AND BALAKRISHNAN, P.P., (2009), "Socio-economic profile of rural women and the role of animal husbandry intervention in suicide affected district of Kerala". J. Hu. Ecol., 27(1): 41-44. 
[5]. GOPALAN, C., RAMA SASTRI, B.V., BALASUBRAMANIAN, S. C., RAO, B.S.N., DEOSHALE, Y. G. AND PANT, K. C., 2007, Nutritive value of Indian foods. National Institute of Nutrition, Hyderabad.47-58.

[6]. GURUMEETH, S. AND GURUDARSHAN, S., (2011), "Socio-economic status of small and marginal farmers and without subsidiary occupation in central Punjab".Ind. J. Soci.Resear.,52(2): 183-189.

[7]. KAVITHA, V. AND DEEPA, P., (2013), "Emerging preferences for processed foods among working and a non-working women". Annals of Agri-Bio-Resear.,18(1): 94-97.

[8]. MAMATHA, D. AND CHAYA, B., 2012 Awareness and opinion of devadasis on selected income generating activities.Kar. J. Agric. Sci., 25(1): 120-123.

[9]. MASANTA, N.C. AND PRADHAN, N.K., (2011), Comparison of nutritional status among the rural and tribal women in Midnapore District of East India". Indian Biologist.,43(1/2): 75-80.

[10]. RAKSHA, RITA, G., AND LALI, Y., (2011), "Constraints faced by rural women in procurement and utilization of credit facilities in Hissardistrict".J. Rese ANGRAU., 4(4): 29-35.

[11]. REVANNA, M.L., (2006), "Impact of WYTEP on empowerment and nutritional status of farm women: A study in Mandya District. PhD Thesis", University of Agricultural sciences, Bangalore.

[12]. TARA, N. AND NEGI, V., 2012, Rural women involvement in selected entrepreneurial activities. Adv Res J. Soc. Sci., 3(1): 63-67.

[13]. THIMMAYAMMA, B. V. S., 1987, A handbook of schedules and guidelines in socio economic and diet survey, National Institute of Nutrition, ICMR, Jamia -Osmania, Hyderabad,40-42

[14]. VEENA, B., (2009), "Entrepreneurship development through value added products from soya". Ph.D. Thesis, UAS, Bengaluru.

[15]. VIJAYALAKSHIM, D., JAMUNA, K.V. AND GOWDA, N.K., (2008), "Impact of training on value addition and nutrition on the empowerment of SHG members, National seminar on SHG for rural upliftment emerging extension issues and strategies", Tiruchirapalli, Tamilnadu, pp: 138 .

Table-1: Socio-Economic Characteristics of Rural Women

\begin{tabular}{|c|c|c|c|}
\hline \multirow{2}{*}{ Sl.No. } & \multirow{2}{*}{ Variables } & \multicolumn{2}{|c|}{ Respondents $(\mathrm{n}=\mathbf{2 0 0})$} \\
\hline & & No. & Per cent \\
\hline \multirow[t]{4}{*}{1.} & \multicolumn{3}{|l|}{ Age } \\
\hline & $21-25$ years & 130 & 65.00 \\
\hline & $26-35$ years & 62 & 31.00 \\
\hline & $36-40$ years & 08 & 04.00 \\
\hline \multirow[t]{6}{*}{2.} & \multicolumn{3}{|l|}{ Education } \\
\hline & Illiterate & 66 & 33.00 \\
\hline & Middle school & 68 & 34.00 \\
\hline & High school & 24 & 12.00 \\
\hline & SSLC & 28 & 14.00 \\
\hline & Graduate & 14 & 07.00 \\
\hline \multirow[t]{3}{*}{3.} & \multicolumn{3}{|l|}{ Family type } \\
\hline & Joint & 54 & 27.00 \\
\hline & Nuclear & 146 & 73.00 \\
\hline \multirow[t]{4}{*}{4.} & \multicolumn{3}{|l|}{ Family size } \\
\hline & Small (upto 3 members) & 28 & 14.00 \\
\hline & Medium (4-6 members) & 166 & 83.00 \\
\hline & Large (7 and above) & 06 & 03.00 \\
\hline \multirow[t]{5}{*}{5.} & \multicolumn{3}{|l|}{ Land holding } \\
\hline & Marginal farmers (<2.5acres) & 126 & 63.00 \\
\hline & Small farmers (2.5-5.0 acres) & 32 & 16.00 \\
\hline & Medium farmers $(>5.0$ acres $)$ & 22 & 11.00 \\
\hline & Land less & 20 & 10.00 \\
\hline \multirow[t]{6}{*}{6.} & \multicolumn{3}{|l|}{ Occupation } \\
\hline & House wife & 52 & 26.00 \\
\hline & Labourer & 80 & 40.00 \\
\hline & Agriculture with Dairy & 48 & 24.00 \\
\hline & Sericulture & 12 & 6.00 \\
\hline & Other activities & 08 & 4.00 \\
\hline \multirow[t]{5}{*}{7.} & \multicolumn{3}{|l|}{ Family Income / month } \\
\hline & $<$ Rs. 2,000 & 32 & 16.00 \\
\hline & Rs. $2,000-3,000$ & 112 & 56.00 \\
\hline & $>$ Rs. 3,000 & 56 & 28.00 \\
\hline & Total & 200 & 100 \\
\hline
\end{tabular}

Table-2: Existing Women Self -Help Groups in the study area

\begin{tabular}{|l|l|l|l|l|l|l|l|l|l|l|}
\hline $\begin{array}{l}\text { Name of the } \\
\text { village }\end{array}$ & \multicolumn{2}{|l|}{ Venkatahalli } & \multicolumn{2}{l|}{ Heggadehalli } \\
\hline $\begin{array}{l}\text { Name of the } \\
\text { SHG }\end{array}$ & Chandrodaya & Suryodaya & Arunodaya & Kirthini & Nandini & $\begin{array}{l}\text { Chandrodaya } \\
\text { II }\end{array}$ & Jaymatha & Maheshwari & Mookambika & SreeShakthi \\
\hline $\begin{array}{l}\text { No.of } \\
\text { members }\end{array}$ & 21 & 19 & 19 & 21 & 19 & 21 & 20 & 19 & 21 & 20 \\
\hline $\begin{array}{l}\text { Money } \\
\text { collected/ } \\
\text { week (Rs.) }\end{array}$ & 10 & 10 & 10 & 10 & 10 & 10 & 10 & 10 & 10 & \\
\hline Total savings & 46,080 & 21,600 & 21,600 & 15,360 & 15,360 & 10,800 & 46,080 & 38,400 & 21,600 & 10,580 \\
\hline
\end{tabular}


Socio-Economic Characterstics And Food Consumption Pattern Of Rural Women

\begin{tabular}{|c|c|c|c|c|c|c|c|c|c|c|}
\hline (Rs.) & & & & & & & & & & \\
\hline $\begin{array}{l}\text { Average total } \\
\text { lending Rs. @ } \\
2 \% \text { interest } \\
\text { per month }\end{array}$ & 2,880 & 1440 & 1,440 & 960 & 960 & 720 & 2,880 & 2,400 & 1,440 & 756 \\
\hline $\begin{array}{l}\text { No.of years in } \\
\text { operation } \\
(2001-07)\end{array}$ & 6 & 3 & 3 & 2 & 2 & $1 \frac{1}{2}$ & 6 & 5 & 3 & $1 \frac{1}{1} 2$ \\
\hline $\begin{array}{l}\text { Investment of } \\
\text { loan }\end{array}$ & $\begin{array}{l}\text { Purchase of } \\
\text { cattle }\end{array}$ & $\begin{array}{l}\text { Purchase } \\
\text { of sheep }\end{array}$ & $\begin{array}{l}\text { Purchase } \\
\text { of sheep }\end{array}$ & $\begin{array}{l}\text { Education/ } \\
\text { family } \\
\text { rituals }\end{array}$ & $\begin{array}{l}\text { Purchase } \\
\text { of cattle }\end{array}$ & $\begin{array}{l}\text { Education/ } \\
\text { family rituals }\end{array}$ & $\begin{array}{l}\text { Purchase } \\
\text { of cattle }\end{array}$ & $\begin{array}{l}\text { Purchase of } \\
\text { sheep }\end{array}$ & $\begin{array}{l}\text { To start food } \\
\text { processing } \\
\text { unit/tailoring } \\
\text { unit }\end{array}$ & $\begin{array}{l}\text { Education } \\
\text { to children }\end{array}$ \\
\hline
\end{tabular}

Table-3: Existing activities of the rural women in study area

$(\mathbf{n}=\mathbf{2 0 0})$

\begin{tabular}{|l|l|l|}
\hline Existing activities & Number & Per cent \\
\hline Dairy farming & 62 & 31.00 \\
\hline Sheep rearing & 38 & 19.00 \\
\hline Tailoring & 24 & 12.00 \\
\hline Vermicompost & 03 & 1.50 \\
\hline Silk worm rearing & 13 & 6.50 \\
\hline Vegetable marketing & 60 & 30.00 \\
\hline Total & $\mathbf{2 0 0}$ & $\mathbf{1 0 0}$ \\
\hline
\end{tabular}

Table-4:Dietary pattern of rural women

\begin{tabular}{|l|l|l|l|}
\hline Food pattern & Intervals & \multicolumn{2}{l|}{ Respondents } \\
\cline { 2 - 4 } & & No. & Per cent \\
\hline Food habit & Vegetarian & 20 & 10 \\
\cline { 2 - 4 } & Non-vegetarian & 180 & 90 \\
\hline Frequency of Non-veg. Consumption & Weekly once & 37 & 18.5 \\
\cline { 2 - 4 } & Weekly twice & 98 & 49 \\
\cline { 2 - 4 } & Fortnightly & 65 & 32.5 \\
\hline Number of meals consumed per day & Two & 36 & 18 \\
\cline { 2 - 4 } & Three & 164 & 82 \\
\hline Number of times meal prepared per day & Twice & 172 & 86 \\
\cline { 2 - 4 } & Thrice & 28 & 14 \\
\hline
\end{tabular}

Table-5: Mean daily nutrient intake of rural women in comparison with RDA

$(\mathbf{n}=\mathbf{2 0 0})$

\begin{tabular}{|c|c|c|c|c|c|}
\hline \multirow{2}{*}{ Nutrients } & \multirow{2}{*}{ RDA } & \multicolumn{2}{|l|}{ Intake } & \multirow{2}{*}{$\begin{array}{ll}\text { Per } & \text { cent } \\
\text { adequacy }\end{array}$} & \multirow{2}{*}{ 't' value } \\
\hline & & Mean & SD & & \\
\hline Protein $(\mathrm{g})$ & 55 & 35.3 & 12.5 & 64 & $39.94 * *$ \\
\hline Fat $(\mathrm{g})$ & 25 & 16.3 & 7.9 & 65 & $29.18 * *$ \\
\hline Energy K-cal & 2230 & 1850 & 442.3 & 83 & $59.15 * *$ \\
\hline Calcium (mg) & 600 & 695 & 117.6 & 116 & $83.58 * *$ \\
\hline Iron $(\mathrm{mg})$ & 21 & 14.7 & 8.1 & 70 & $14.14 * *$ \\
\hline$\beta$-Carotene (mg) & 4800 & 3600 & 8175.8 & 75 & $62.25 * *$ \\
\hline Thiamin (mg) & 1.1 & 0.8 & 0.4 & 72 & $31.82 * *$ \\
\hline Riboflavin (mg) & 1.3 & 0.8 & 0.3 & 72 & $37.71 * *$ \\
\hline Niacin (mg) & 14 & 11.0 & 4.2 & 78 & $37.04 * *$ \\
\hline
\end{tabular}

** Significant at $1 \%$

Table-6: Correlation co-efficient of independent variables on nutrient intake of rural women

\begin{tabular}{|c|c|c|c|c|c|c|c|c|c|}
\hline \multirow{2}{*}{$\begin{array}{l}\text { Independent } \\
\text { variables }\end{array}$} & \multicolumn{9}{|c|}{ Correlation co-efficient (r) with nutrients } \\
\hline & Protein & Fat & Energy & Calcium & Iron & Thiamine & Riboflavin & $\beta$-carotene & Niacin \\
\hline Age & 0.02412 & 0.04404 & 0.06121 & 0.04857 & 0.04657 & 0.056 & 0.037274 & 0.0629 & -0.0146 \\
\hline Family type & -0.033568 & -0.03538 & 0.02046 & -0.0551 & -0.02467 & -0.0271 & -0.029 & 0.00042 & -0.0077 \\
\hline Family size & -0.005654 & -0.00769 & 0.01712 & 0.00232 & 0.01059 & 0.0009 & -0.02172 & -0.0476 & 0.1198 \\
\hline Education & 0.10407 & 0.09571 & 0.12069 & 0.10697 & 0.11373 & 0.1057 & 0.12017 & 0.11343 & -0.0379 \\
\hline Land holding & 0.1976 & 0.19296 & 0.17591 & 0.19709 & 0.20659 & 0.1953 & 0.183081 & 0.11967 & 0.0381 \\
\hline Income & 0.413187 & 0.37984 & 0.41276 & 0.36704 & 0.41501 & 0.429 & 0.413679 & 0.33565 & -0.1669 \\
\hline
\end{tabular}

